\title{
Biogenic fabrication and characterization of silver nanoparticles using aqueous- ethanolic extract of lichen (Usnea longissima) and their antimicrobial activity
}

\author{
Khwaja Salahuddin Siddiqi ${ }^{1}$, M. Rashid ${ }^{2}$, A. Rahman², Tajuddin², Azamal Husen ${ }^{3 *}$ (D) and Sumbul Rehman ${ }^{4}$
}

\begin{abstract}
Background: Biogenic fabrication of silver nanoparticles from naturally occurring biomaterials provides an alternative, eco-friendly and cost-effective means of obtaining nanoparticles. It is a favourite pursuit of all scientists and has gained popularity because it prevents the environment from pollution. Our main objective to take up this project is to fabricate silver nanoparticles from lichen, Usnea longissima and explore their properties. In the present study, we report a benign method of biosynthesis of silver nanoparticles from aqueous-ethanolic extract of Usnea longissima and their characterization by ultraviolet-visible (UV-vis), Fourier transform infrared (FTIR) spectroscopy, transmission electron microscopy (TEM) and scanning electron microscopy (SEM) analyses. Silver nanoparticles thus obtained were tested for antimicrobial activity against gram positive bacteria and gram negative bacteria.
\end{abstract}

Results: Formation of silver nanoparticles was confirmed by the appearance of an absorption band at $400 \mathrm{~nm}$ in the UV-vis spectrum of the colloidal solution containing both the nanoparticles and U. longissima extract. Poly(ethylene glycol) coated silver nanoparticles showed additional absorption peaks at 424 and $450 \mathrm{~nm}$. FTIR spectrum showed the involvement of amines, usnic acids, phenols, aldehydes and ketones in the reduction of silver ions to silver nanoparticles. Morphological studies showed three types of nanoparticles with an abundance of spherical shaped silver nanoparticles of 9.40-11.23 nm. Their average hydrodynamic diameter is $437.1 \mathrm{~nm}$. Results of in vitro antibacterial activity of silver nanoparticles against Staphylococcus aureus, Streptococcus mutans, Streptococcus pyrogenes, Streptococcus viridans, Corynebacterium xerosis, Corynebacterium diphtheriae (gram positive bacteria) and Escherichia coli, Klebsiella pneuomoniae and Pseudomonas aeruginosa (gram negative bacteria) showed that it was effective against tested bacterial strains. However, S. mutans, C. diphtheriae and P. aeruginosa were resistant to silver nanoparticles.

Conclusion: Lichens are rarely exploited for the fabrication of silver nanoparticles. In the present work the lichen acts as reducing as well as capping agent. They can therefore, be used to synthesize metal nanoparticles and their size may be controlled by monitoring the concentration of extract and metal ions. Since they are antibacterial they may be used for the treatment of bacterial infections in man and animal. They can also be used in purification of water, in soaps and medicine. Their sustained release may be achieved by coating them with a suitable polymer. Silver nanoparticles fabricated from edible U. longissima are free from toxic chemicals and therefore they can be safely used in medicine and medical devices. These silver nanoparticles were stable for weeks therefore they can be stored for longer duration of time without decomposition.

Keywords: Biosynthesis, Usnea longissima, Silver nanoparticles, Electron microscopy, Antimicrobial activity

\footnotetext{
* Correspondence: adroot92@yahoo.co.in

${ }^{3}$ Department of Biology, College of Natural and Computational Sciences,

University of Gondar, P.O. Box \#196, Gondar, Ethiopia

Full list of author information is available at the end of the article
}

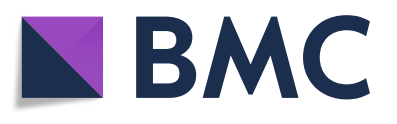

(c) The Author(s). 2018 Open Access This article is distributed under the terms of the Creative Commons Attribution 4.0 International License (http://creativecommons.org/licenses/by/4.0/), which permits unrestricted use, distribution, and reproduction in any medium, provided you give appropriate credit to the original author(s) and the source, provide a link to the Creative Commons license, and indicate if changes were made. The Creative Commons Public Domain Dedication waiver (http://creativecommons.org/publicdomain/zero/1.0/) applies to the data made available in this article, unless otherwise stated. 


\section{Background}

Metal nanoparticles (NPs) have attracted much attention during recent years owing to their unique properties which are different from bulk material. These particles gained importance during recent years owing to their broad-spectrum application in a number of processes such as agriculture, cosmetics, healthcare, drug or gene delivery, medical devices, biosensor and catalysis [1-9] besides their antimicrobial properties [2, 10, 11]. Many metal NPs are essential nutrients to living system while some are toxic [12]. Their efficiency depends on their shape and size. Among the coinage metals silver has highest thermal and electrical conductivity. They may have multidimensional structure such as nanotubes and nanowires. A variety of methods for the fabrication of NPs have been developed but reduction reaction, photochemical reaction, thermal decomposition, electrochemical, sono-chemical and microwave assisted methods are prevalent these days. Although, these synthetic procedures are effective and high yielding they require chemicals which are often toxic and pollute the environment. However, these methods are not economical and sometime require expensive and hazardous chemicals which are difficult to handle. Green method of NP synthesis using plant extracts, bacteria, actinomycetes, fungi and enzymes are therefore, frequently used because of their environment friendly nature and bio compatibility [2, 13-16]. Major compounds found in plant extracts are generally glycosides, alkaloids, phenols, quinines, amines and terpenoids which convert silver ions to silver nanoparticles (Ag NPs) [2, 11]. Thus leaves, bark, flowers and seed extract of plants containing above chemicals are used as a source of reducing agents. For instance, Dhand et al. [17] have reported green synthesis of Ag NPs from roasted Coffea arabica seed extract. They were found to be highly crystalline with spherical and ellipsoidal shape. Average particle size ranged between 10 and $150 \mathrm{~nm}$. It was observed that the particle size increased with decreasing concentration of $\mathrm{AgNO}_{3}$ solution. They were also effective against Escherichia coli and Streptococcus aureus. It was noted that smaller Ag NPs were more effective than the larger ones. In another study biosynthesis, biocompatibility and antibacterial activity of Adathoda vasica extract mediated Ag NPs have been thoroughly studied [18]. They showed significant antibacterial activity against Vibrio parahaemolyticus but were non-toxic to Artemia naupli. Since Vibrio parahaemolyticus causes vibriosis in shrimps (early mortality syndrome) biosynthesized Ag NPs have been used to protect them from this disease [19]. Vibrio infection also causes high mortality in Siberian tooth carps, milk fish, abalone and shrimps [20-22]. Overuse of vaccines and antibiotics have made them resistant. Since Ag NPs are known antibacterial substance they have been green synthesized from plant material and used frequently to prevent bacterial infections which are resistance to trivial drugs $[2,11]$.

The lichen, Usnea longissima belonging to Usneaceae family grows as moss on trees in temperate climate. They are slowest growing plants living in symbiosis with algae, fungi and perennial trees. Different genera of lichens are used in curing dyspepsia, amenorrhea and vomiting. Lichens produce secondary metabolites which are used as crude drugs. It contains mainly usnic acid and its derivatives called usenamines, usone and iso-usone [23]. Three compounds containing $\mathrm{OH}$ and $\mathrm{NH}_{2}$ groups have been shown to inhibit the growth of human hepatoma, HepG2 cells with significant IC50 values between $6.0-53.3 \mu \mathrm{M}$. This value is lower than that found for methotrexate (IC50 value of $15.8 \mu \mathrm{M}$ ) under the same condition. U. longissima exhibits myriad biological properties such as antitumor, antiviral, antimicrobial, anti-inflammatory and insecticidal activities. Since it is known to damage the liver, its application in human system is limited [24-26] even though it is used to treat ascariasis [27] and fractured bones. Its extract is known to contain monosubstituted phenyls, depsides, anthraquinones, dibenzofurans and terpenoides which have been shown to exhibit insecticidal and antioxidant activities [23, 28-30]. A number of bacteria and fungi (E. coli, Candida albicans, Bacillus subtilis, Mycobacteriun smegmatis, Trichophyton rubrum and Aspergillus niger) have been used to investigate the in vitro activity of usnic acid derivatives [23, 31, 32]. Usnic acid derivatives are cytotoxic and antimicrobial it is also used as an expectorant and in the treatment of ulcer. It has been shown by Nishitoba et al. [28] that all depsides and orcinol derivatives of $U$. longissima act as growth inhibitor of lettuce seedlings. Inhibition of tumour promoter induced Epstein-Barr virus by $U$. longissima extract has been shown to exhibit highest inhibition activity [33]. Methanol extract of $U$. longissima has also exhibited antioxidant activity [34]. Antiulcerogenic effect of $U$. longissima water extract against indomethacin induced ulcer in rat has been investigated [29]. The extract showed moderate antioxidant activity when compared with trolox and ascorbic acid as positive antioxidant [29]. Biosorption of trace amounts of $\mathrm{Au}(\mathrm{III})$ and $\mathrm{Cu}(\mathrm{II})$ by $U$. longissima biomass has been investigated [35]. It is surprising that effective absorption of both the metals occurs either at $\mathrm{pH} 2$ or $\mathrm{pH} 8$ within $75 \mathrm{~min}$. It has been found that $1 \mathrm{~g}$ of dry lichen absorbed $9.4 \mathrm{mg} \mathrm{Au}$ (III) and $24.0 \mathrm{mg} \mathrm{Cu}(\mathrm{II})$. The recovery of metals is nearly quantitative (>90\%).

Several compounds from $U$. longissima have been isolated and identified but no effort seems to have been made to synthesis Ag NPs. Although, Ag NPs alone have numerous qualities, bio-functionalized NPs are more 
effective against pathogenic microbes such as bacteria, virus and fungi. Biosynthesized Ag NPs using edible $U$. longissima is free from toxic chemicals and hence they can be safely used in medicine and medical devices. We are, therefore, reporting, for the first time, the biosynthesis of Ag NPs from $U$. longissima in 50:50 water- ethanol extract and their characterization by ultraviolet-visible (UV-vis), Fourier transform infrared (FTIR) spectroscopy, size distribution, transmission electron microscopy (TEM) and scanning electron microscopy (SEM) analyses. Their antibacterial activity against some clinical isolates of bacterial strains (six-gram positive and three-gram negative) has also been investigated.

\section{Methods}

\section{Chemicals, plant material and instrumentation}

$\mathrm{AgNO}_{3}$ (Merck, India Ltd.), ethanol (AR grade) and double distilled water were used. Aqueous solution of poly(ethylene glycol) (Merck, India Ltd.) was used. Usnea longissima was procured from the pharmacy unit of Aligarh Muslim University, Aligarh, India (Fig. 1). UV-vis spectral measurements were done with an Elico Spectrophotometer between 200 and $500 \mathrm{~nm}$. Size distribution was determined by Malvern Instruments Ltd., Zetasizer Ver. 7.11. FTIR spectra were recorded with Perkin-Elmer Spectrometer, FTIR spectrum ONE, in $4000-400 \mathrm{~cm}^{-1}$ region as $\mathrm{KBr}$ disc. TEM Images of $\mathrm{Ag}$ NPs were obtained using JEOL, JEM 2100 transmission electron microscope at $190 \mathrm{KV}$. Samples were prepared using a drop of colloidal solution of Ag NPs on a carbon coated copper grid and allowing the above sample to completely dry in a vacuum desiccator. The sediment particles obtained were used for scanning FTIR spectra. SEM images were obtained with JEOL, JSM 6510LV scanning electron microscope.

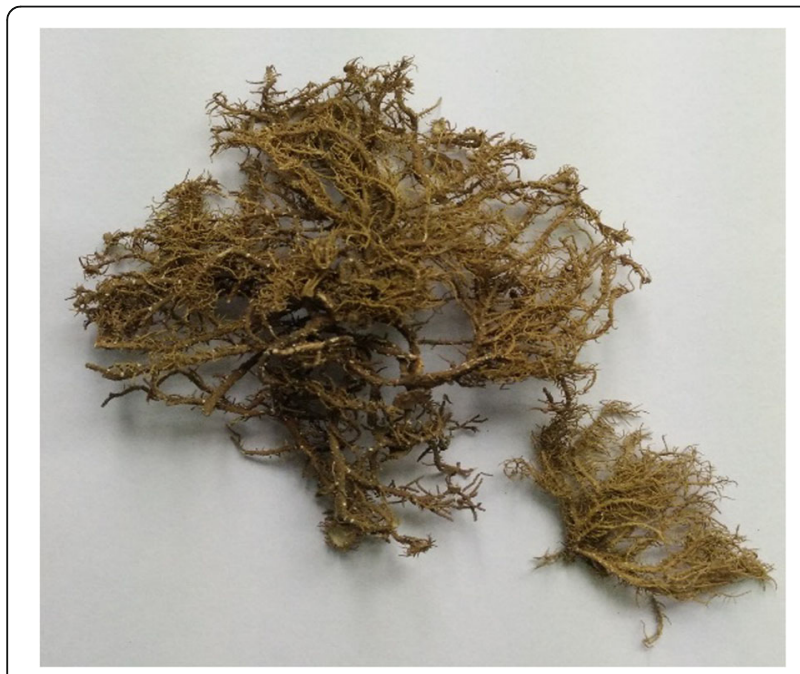

Fig. 1 Usnea longissima

\section{Synthesis of ag NPs}

Ag NPs were prepared from aqueous-ethanolic extract of $U$. longissima. Lichen was gently washed with distilled water to remove dust. It was subsequently dried at $60^{\circ} \mathrm{C}$ and powdered. Ten $\mathrm{g}$ of this dry powder was refluxed in $100 \mathrm{ml}$ ethanol-distilled water (50:50) mixture for $3 \mathrm{~h}$, cooled to room temperature and centrifuged at $10,000 \mathrm{rpm}$ to remove the solid mass. Ten $\mathrm{ml}$ of this extract at $\mathrm{pH} 7$ was taken in an Erlenmeyer flask and $1 \mathrm{ml}$ of $0.01 \mathrm{M}$ solution of $\mathrm{AgNO}_{3}$ was added to start the reduction of silver ions to Ag NPs. The mixture was vigorously stirred on a magnetic stirrer for ten to fifteen min and incubated in dark to protect the contents from sunlight. Colour change was regularly monitored. Reaction was completed only after $72 \mathrm{~h}$ showing purple colour. Reaction mixture was then centrifuged at $10,000 \mathrm{rpm}$ to separate NPs from the liquid. It was decanted and the supernatant was further centrifuged to isolate any NP left in the solvent. The sample thus obtained was stable for weeks although the yield was very low (35\%). All manipulations were done at ambient temperature.
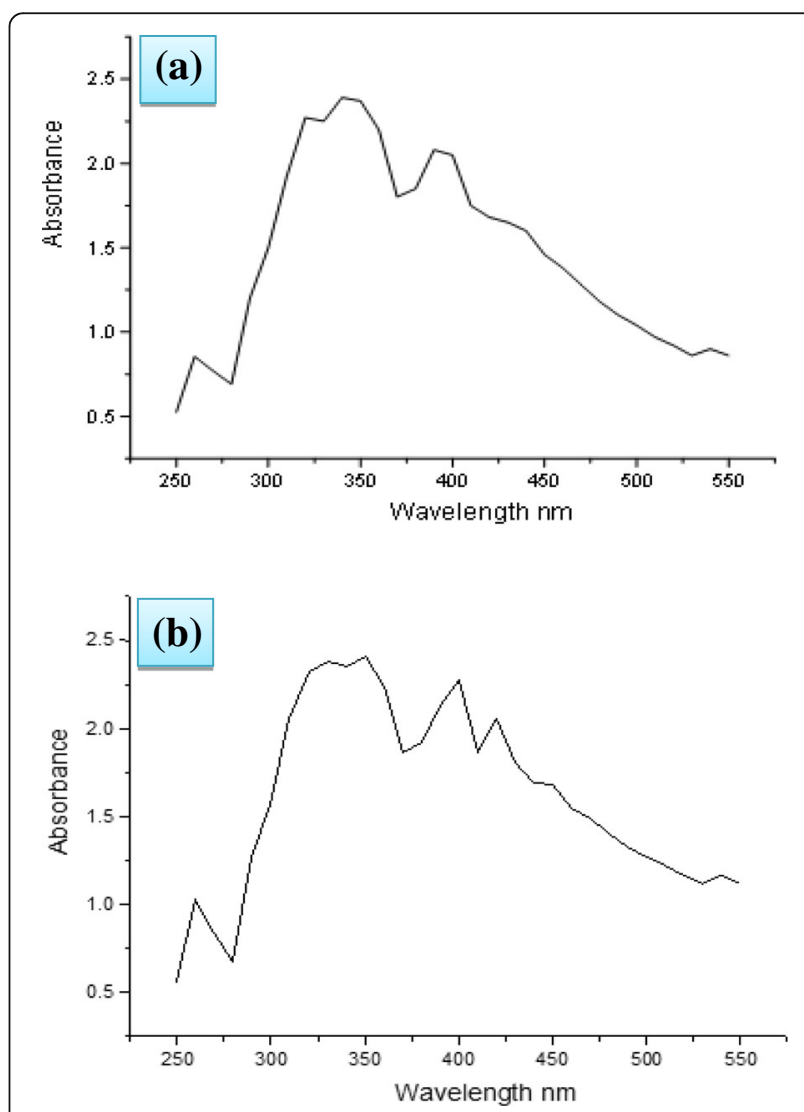

Fig. 2 UV-vis spectrum of (a) silver nanoparticles and (b) poly(ethylene glycol) coated silver nanoparticles at $25^{\circ} \mathrm{C}$ 


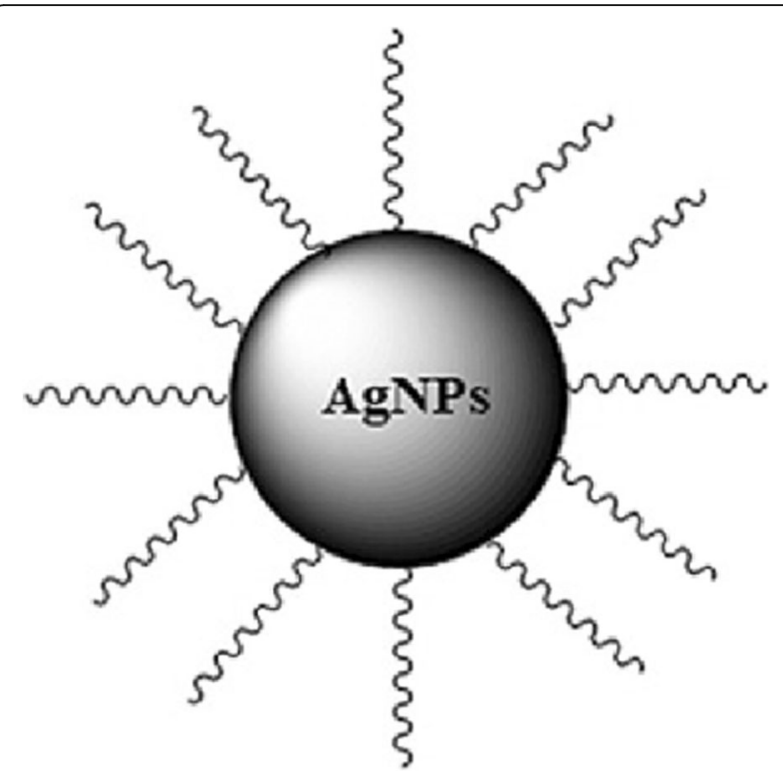

Fig. 3 Poly(ethylene glycol) coated silver nanoparticles

\section{Evaluation of antibacterial activity}

Ag NPs thus obtained were tested for antimicrobial activity against Staphylococcus aureus, Streptococcus mutans, Streptococcus pyrogenes, Streptococcus viridans, Corynebacterium diphtheriae and Corynebacterium xerosis (six-gram positive bacteria) and Escherichia coli, Klebsiella pneuomoniae and Pseudomonas aeruginosa (three-gram negative bacteria) obtained from Department of Microbiology, Jawaharlal Nehru Medical College \& Hospital, Aligarh Muslim University, Aligarh, India. The solid media namely Nutrient Agar No.2 (NA) (M 1269S-500G, Himedia Labs Pvt. Ltd., Bombay, India) was used for preparing nutrient plates, while Nutrient Broth (NB) (M002-500G, Himedia Labs Pvt. Ltd.,
Bombay, India) was used for the liquid culture media. Antibacterial activity was evaluated by agar well diffusion method. All the microbial cultures were adjusted to 0.5 McFarland standards, which is visually comparable to a microbial suspension of $1.5 \times 10^{8} \mathrm{cfu} / \mathrm{ml}$. Agar medium $(20 \mathrm{ml})$ was poured into each petri plate and were swabbed with a colony from the inoculums of the test microorganisms and kept for 15 min for adsorption. Using sterile cork borer of $6 \mathrm{~mm}$ diameter wells were bored into the seeded agar plates. They were loaded with $100 \mu \mathrm{l}$ of dimethylsulphoxide (DMSO) of $2 \mathrm{mg} / \mathrm{ml}$. All the plates were incubated at $37{ }^{\circ} \mathrm{C}$ for $24 \mathrm{~h}$. Antimicrobial activity was evaluated by measuring the zone of growth inhibition against the tested gram positive and gram negative bacteria with Antibiotic Zone Scale (PW297, Himedia Labs Pvt. Ltd., Mumbai, India), which was held over the back of the inverted plate. It was held a few inches above a black, non-reflecting background and illuminated with reflected light. The medium with DMSO as solvent was used as a negative control whereas media with Ciprofloxacin $(5 \mu \mathrm{g} /$ disk as standard antibiotic for gram positive) and Gentamicin $(10 \mu \mathrm{g} / \mathrm{disk}$ as standard antibiotic for gram negative) were used as positive control. The experiments were performed in triplicates.

\section{Results and discussion}

\section{UV-vis spectra}

It is known that when Ag NPs are formed, colour of the solution containing both the NPs and plant extract turns dark brown or purple depending on the presence of organic molecules in the extract. In our case, $\mathrm{AgNO}_{3}$ was mixed with aqueous- ethanolic extract of $\mathcal{U}$. longissima and incubated at room temperature; its colour turned purple after $72 \mathrm{~h}$. It did not show any significant change

\section{Size Distribution by Intensity}

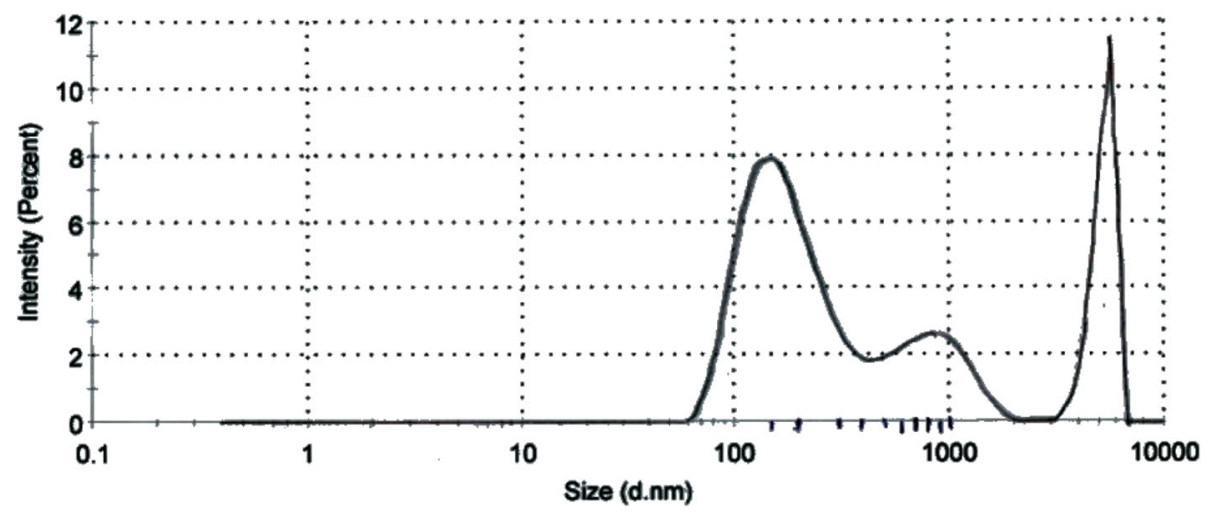

Fig. 4 Particle size distribution of Usnea longissima mediated silver nanoparticles 
thereafter which confirms the formation of Ag NPs according to the following equation.

$$
\mathrm{AgNO}_{3}+\mathrm{NR}_{3}=\mathrm{Ag}^{0}+\mathrm{NR}^{+}+\mathrm{H}^{+}+\mathrm{NO}_{3}^{-}
$$

The UV-vis spectrum of this colloidal solution was run from 200 to $500 \mathrm{~nm}$ at room temperature which displayed peaks at 350 and $400 \mathrm{~nm}$. Highest peak at $400 \mathrm{~nm}$ has been attributed to the excitation of surface plasmon resonance (SPR) of Ag NPs (Fig. 2a). Photo-oxidation of chemical constituents present in the extract may also have occurred [36]. Profile of the UV-vis spectrum depends on the concentration of substrate and silver ions. However, when aqueous solution of poly(ethylene glycol) - PEG, was added to the above solution, new peaks at 424 and $450 \mathrm{~nm}$ were observed (Fig. 2b). It is probably due to coating of Ag NPs with the polymer as shown in figure (Fig. 3). Colour of these NPs remained unchanged even after several weeks [37]. It has been observed that when the colloidal solution containing $\mathrm{Ag} \mathrm{NP}$ is slowly heated up to $60{ }^{\circ} \mathrm{C}$ the colour intensity increases with increasing temperature and NPs are quickly formed. It demonstrates the effect of temperature on the biosynthesis of Ag NPs. Absorption peaks in the UV-vis spectrum are related to the shape of Ag NPs. According to the criterion of Zhang and Nogues [38] the peaks at 385, 435, 465 and $515 \mathrm{~nm}$ correspond to cubical Ag NPs, those at 462 for truncated cubes, at 430 cuboctahedral and $400 \mathrm{~nm}$ peak for spherical NPs. Since we have observed major peak at $400 \mathrm{~nm} \mathrm{Ag} \mathrm{NPs} \mathrm{are} \mathrm{supposed} \mathrm{to} \mathrm{be} \mathrm{mainly} \mathrm{spherical}$ though the presence of small amount of other types of NPs cannot be ignored.

Size distribution was performed using water as dispersant at a count rate of $271.6 \mathrm{k}$ cps. There are three types of Ag NPs present in the colloidal solution. Their hydrodynamic diameters are very large as shown in Fig. 4. However, the peak-1 shows the abundance of particles with average hydrodynamic diameter of $184.5 \mathrm{~nm}$ with an intensity of $59.4 \%$ but overall average is $437.1 \mathrm{~nm}$. This may be due to aggregation of the particles in the solvent. The hyddrated NPs are always larger than the isolated ones because of the aggregation of water molecules around them. Since the surface area of aggregated NPs is decreased they would not be in direct contact with microbes and their antibacterial efficiency will obviously decrease.

\section{TEM and SEM}

TEM images (Fig. 5) showed that Ag NPs in our case are mainly spherical in shape. There is very narrow range in the size of NPs. Average particle size varies between 9.4 and $11.83 \mathrm{~nm}$. TEM images

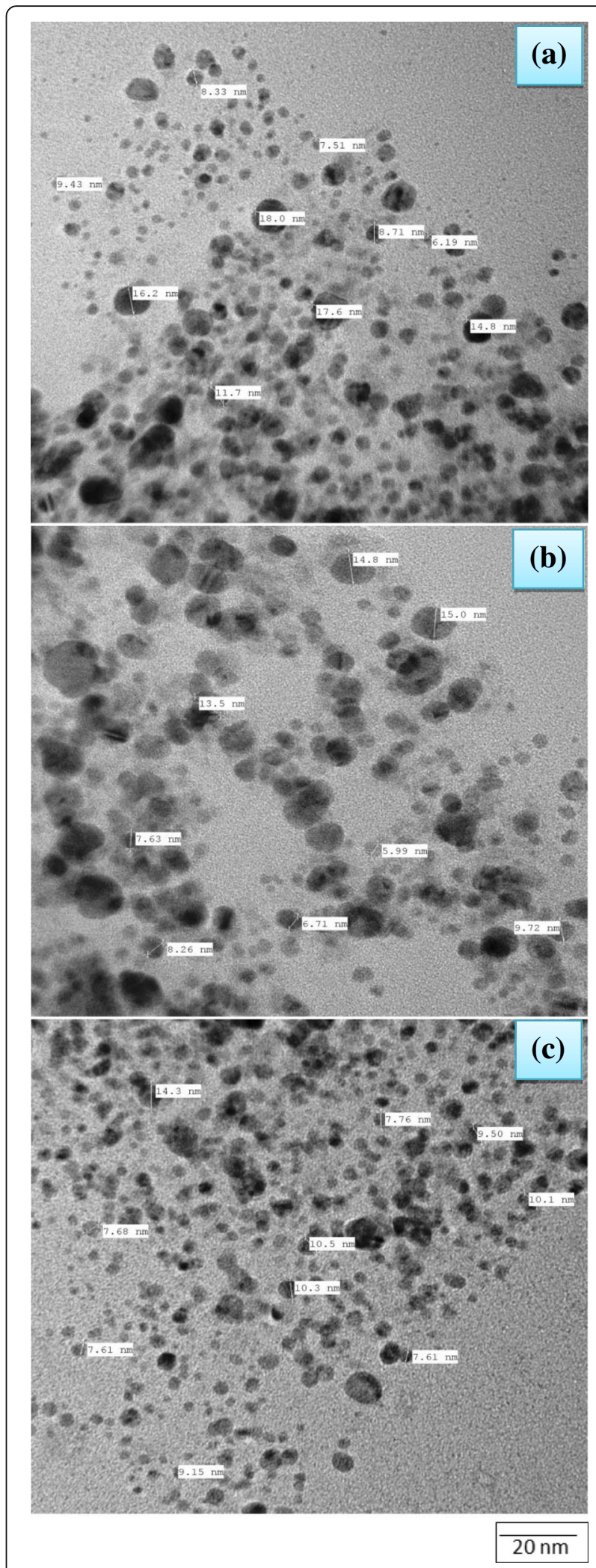

Fig. 5 TEM images of silver nanoparticles; (a) under 80,000 magnification (average size, $11.83 \mathrm{~nm}$ ), (b) under 100,000 magnification (average size, $10.20 \mathrm{~nm}$ ) and (c) under 80,000 magnification (average size, $9.44 \mathrm{~nm}$ ) 


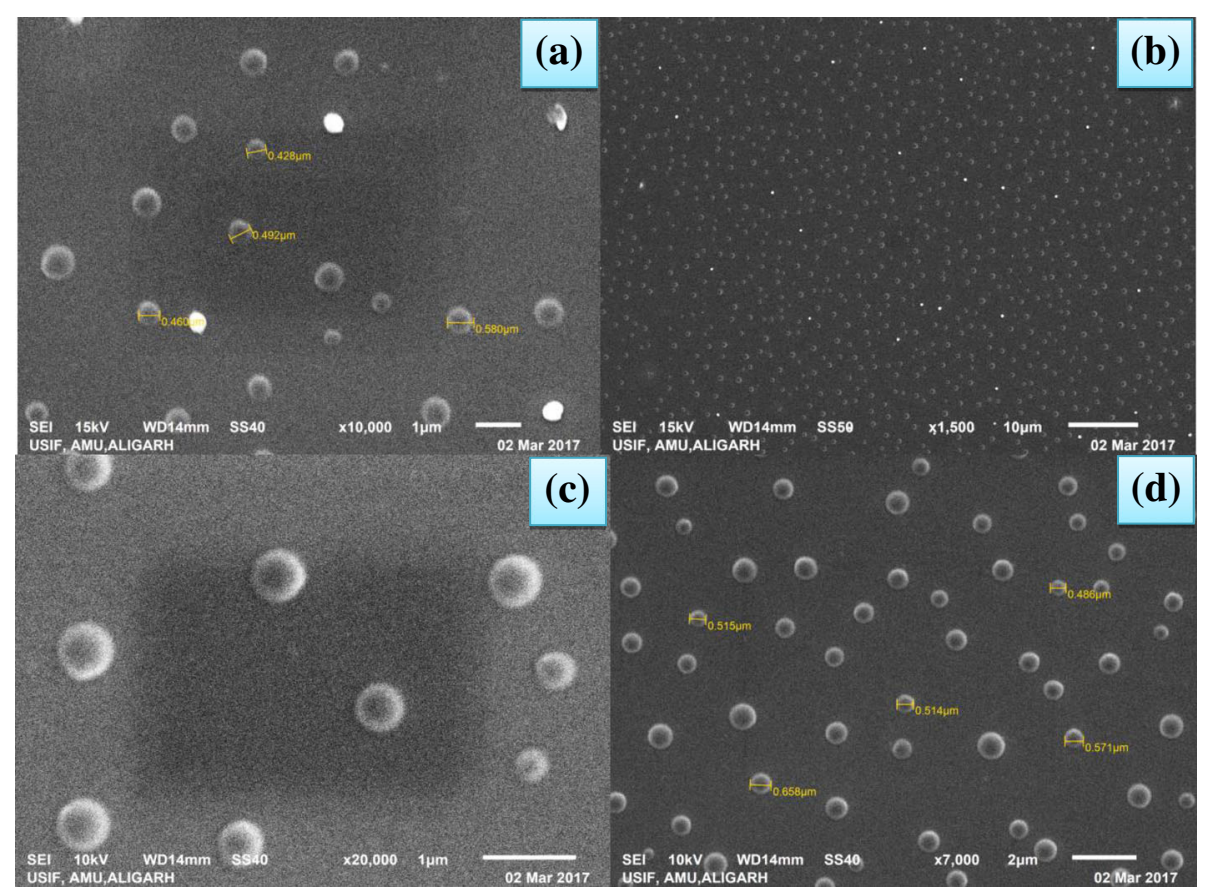

Fig. 6 SEM images of silver nanoparticles; (a) under 10,000 magnification, (b) under 1500 magnification, (c) under 20,000 magnification and (d) under 7000 magnification.

show spherical morphology with an average size of $10.49 \mathrm{~nm}$ (Fig. 5a-c). It has also been observed that these are much smaller in size than those recently reported [39].

The topology and size were also confirmed by SEM images (Fig. 6a-d) showing the presence of small and uniformly spherical shaped Ag NPs with smooth surface and very narrow distribution range of 9.4-11.83 nm [40]. The larger particles are formed due to aggregation of Ag NPs otherwise they appear to be segregated. The cluster must have been formed due to evaporation of the solvent during sample preparation. The scattered shiny dots appearing in the SEM images are due to uncoated free $\mathrm{Ag}$ NPs which look like shining stars in milkyway (Fig. $6 \mathrm{~b})$ in dark night [41].

\section{IR spectrum}

FTIR spectrum was run to identify the involvement of biomolecules present in $U$. longissima extract for the reduction of $\mathrm{AgNO}_{3}$ to Ag NPs. It is known to contain phenol, amines, aldehydes and ketones besides many other compounds in traces. However, usnic acid and usenamine (Fig. 7) are dominant compounds in aqueous- ethanolic extract of $U$. longissima which interact with $\mathrm{AgNO}_{3}$. Since all these compounds are excellent reducing agents, they undergo changes in stretching frequencies of their functional groups as a consequence of reduction of $\mathrm{AgNO}_{3}$ to $\mathrm{Ag}$ NPs. IR spectrum (Fig. 8) is very complicated because of the overlap of frequencies in the same region. However, we have attempted to identify the shifts in stretching vibrations after the formation of Ag NPs. Primary amines exhibit two N-H stretching

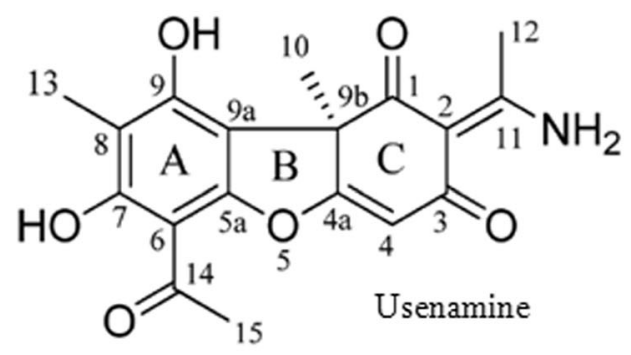

Usenamine

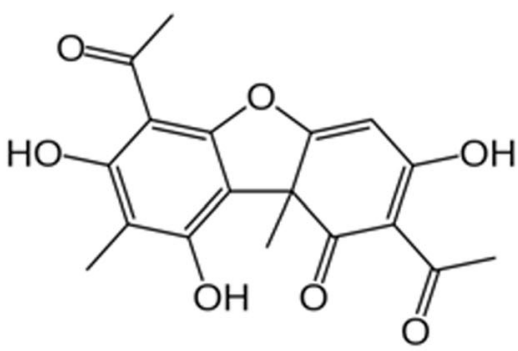

Usnic Acid

Fig. 7 Structures of usenamine and usnic acid 

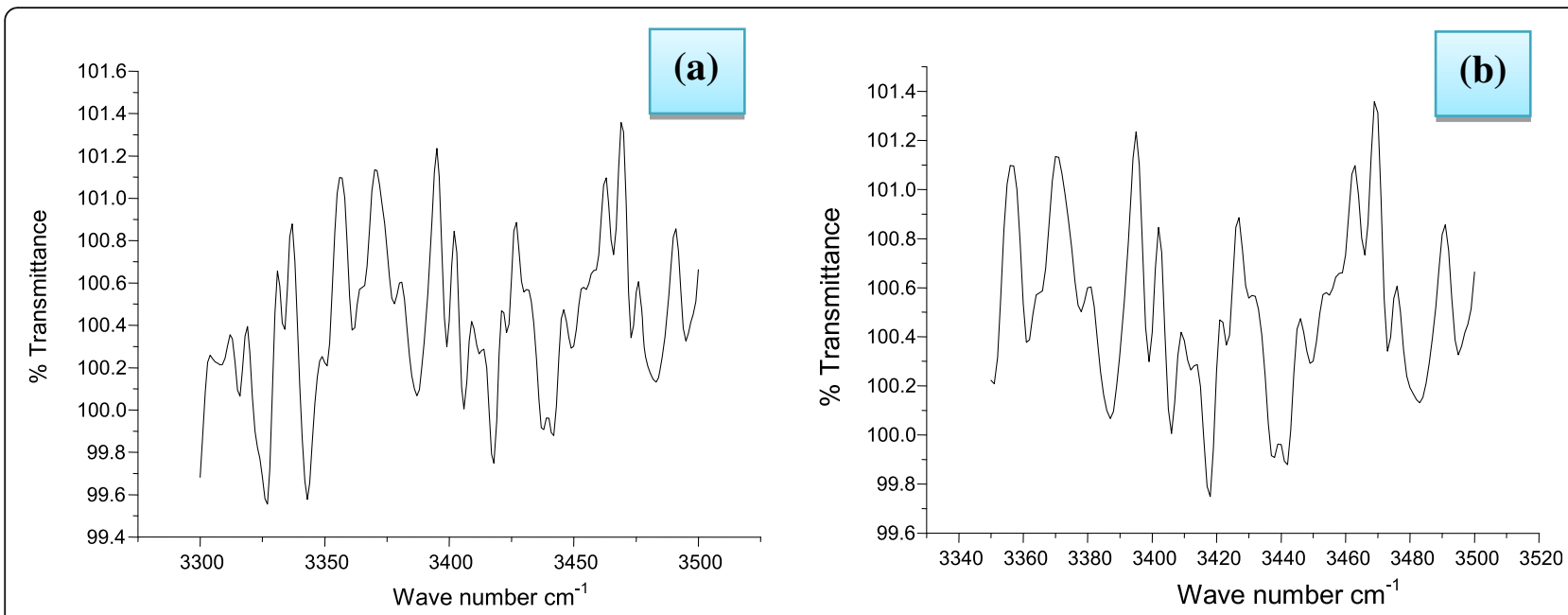

Fig. 8 FTIR spectra of (a) aqueous-alcoholic extract and (b) silver nanoparticles

frequencies in $3500-3300 \mathrm{~cm}^{-1}$ region which have been found to appear at 3400 and $3455 \mathrm{~cm}^{-1}$ in the NPs containing $U$. longissima extract (Fig. 8). The band in $1600-1500 \mathrm{~cm}^{-1}$ are due to CO stretching but amide bands also appear in the same region of spectrum. We have observed amide I and amide II bands at 1650 and $1540 \mathrm{~cm}^{-1}$. A band at $1560 \mathrm{~cm}^{-1}$ has been assigned to $(\mathrm{C}=\mathrm{O})$ stretching frequency. The $\mathrm{COO}^{-}$group generally appears above $1600 \mathrm{~cm}^{-1}$ but overlaps with amide II band [42]. These spectral results indicate the involvement of organic molecules in the reduction of $\mathrm{AgNO}_{3}$ leading to the formation of Ag NPs.

\section{Antibacterial screening}

Results of in vitro antibacterial activity of Ag NPs against Staphylococcus aureus, Streptococcus mutans, Streptococcus pyrogenes, Streptococcus viridans, Corynebacterium diphtheriae and Corynebacterium xerosis (gram positive bacteria) and Escherichia coli, Klebsiella pneuomoniae and Pseudomonas aeruginosa (gram negative bacteria) are presented in Table 1. The zone of inhibition suggests that Ag NPs are weekly toxic to both gram positive and gram negative bacteria. Ag NPs with larger surface area provide a better contact with microorganisms $[2,6,11]$. Thus, these particles may penetrate the bacterial cell membrane or attach to the bacterial surface and inhibit their replication [43, 44]. In our experiment, Ag NPs have been found to be most effective against $E$. coli. It has been reported that antibacterial efficiency is increased by lowering the particle size [45]. Usually NPs attach on the cell wall of bacteria and damage membrane and respiration system leading to cell death [11, 43]. Toxicity of smaller NPs was greater than those of larger ones because the smaller ones can easily adhere to bacterial cell wall $[11,46]$.

\section{Mechanism of action}

Silver ions penetrate into cytoplasm; denature the ribosome leading to the suppression of enzymes and proteins which eventually arrest their metabolic function resulting in apoptosis of bacteria. Bactericidal activity is due to silver ions released from Ag NPs as a consequence of their

Table 1 Mean zone of inhibition (in $\mathrm{mm}$ )

\begin{tabular}{llll}
\hline Bacterial strains & Silver nanoparticles & Negative control* & Positive control** $^{*}$ \\
\hline Staphylococcus aureus & $10.6 \pm 0.50^{\mathrm{a}}$ & $6.2 \pm 0.20$ & $28.0 \pm 0.89$ \\
Streptococcus mutans & $6.5 \pm 0.89^{\mathrm{a}}$ & $5.8 \pm 0.40$ & $29.2 \pm 0.83$ \\
Streptococcus pyrogenes & $15.6 \pm 0.40^{\mathrm{a}}$ & $6.2 \pm 0.20$ & $29.2 \pm 0.48$ \\
Streptococcus viridans & $14.6 \pm 0.24^{\mathrm{a}}$ & $6.2 \pm 0.20$ & $25.6 \pm 0.20$ \\
Corynebacterium xerosis & $13.6 \pm 0.50^{\mathrm{a}}$ & $6.2 \pm 0.20$ & $22.8 \pm 0.58$ \\
Corynebacterium diphtheriae & $6.2 \pm 0.37^{\mathrm{a}}$ & $6.2 \pm 0.20$ & $22.2 \pm 0.48$ \\
Escherichia coli & $20.8 \pm 0.02^{\mathrm{a}}$ & $6.2 \pm 0.20$ & $26.8 \pm 0.48$ \\
Klebsiella pneuomoniae & $16 \pm 0.31^{\mathrm{a}}$ & $6.2 \pm 0.20$ & $26.4 \pm 0.24$ \\
Pseudomonas aeruginosa & $7 \pm 0.31^{\mathrm{a}}$ & $6.2 \pm 0.20$ & $21.8 \pm 0.37$ \\
\hline
\end{tabular}

Values are expressed as mean \pm SD $(n=3)$ and valued followed by same letter are not significantly different at the $p<0.0001$ as determined by Duncan's Multiple Range Test; * indicates dimethyl sulphoxide, ${ }^{* *}$ indicates standard drug (Ciprofloxacin for gram positive and Gentamicin for gram negative bacterial strains) 
interaction with microbes [11]. However, four possible mechanisms of antibacterial activity of Ag NPs have been proposed (i) interference during cell wall synthesis (ii) suppression during protein biosynthesis (iii) disruption of transcription process and (iv) disruption of primary metabolic pathways [17]. Each mechanism involves structural changes, biochemical changes and charges on both the silver ions and bio molecules in the microbial cells. Ag NPs also inhibit the proliferation of cancer cell lines by different modes of action [47]. They mediate and amplify the death signal by triggering the activation of Caspase- 3 molecule. The DNA splits into fragments by Caspase- 3 . Ag NPs may interfere with the proper functioning of cellular proteins and induce subsequent changes in cellular chemistry. Sometimes Ag NPs alter the function of mitochondria by inhibiting the catalytic activity of lactate dehydrogenase. Ag NPs may also cause proliferation of cancer cells by generating ROS which ultimately leads to DNA damage.

\section{Conclusion}

Few species of lichens have rarely been exploited in the production of NPs; in the present investigation we successfully fabricated Ag NPs by bio-reduction of silver nitrate from aqueous-alcoholic extract of $U$. longissima at room temperature. Size distribution shows the presence of three types of Ag NPs, the average diameter of which is $437.1 \mathrm{~nm}$. However, NPs with hydrodynamic diameter of $184.5 \mathrm{~nm}$ are in abundance. It has been observed from SEM images that NPs are mainly spherical in shape. There is not very large variation in their size $(9.4-11.3 \mathrm{~nm})$. Ag NPs are antibacterial and their sustained release may be achieved by coating them with a suitable polymer. They are highly effective against $E$. coli and $K$. pneuomoniae, although S. mutans, $C$. diphtheriae and $P$. aeruginosa are resistant to it. In the present work, the lichen acts as reducing as well as capping agent. These Ag NPs were stable for weeks therefore they can be stored for longer duration of time. However, their slow oxidation to silver ions cannot be prevented.

\section{Acknowledgements}

Authors are thankful to Prof. Wazahat Husain, Department of Botany, Aligarh Muslim University, Aligarh, India for plant identification; and Department of Microbiology, Jawaharlal Nehru Medical College \& Hospital, Aligarh Muslim University, Aligarh, India for providing bacterial culture.

\section{Availability of data and materials}

The datasets supporting the results of this article are included in the article.

\section{Authors' contributions}

All authors had significant intellectual contribution towards the design of the study, data collection and analysis; and write-up of the manuscript. All authors read and approved the final manuscript and agreed to its submission.

Ethics approval and consent to participate Not applicable.
Consent for publication

Not applicable.

\section{Competing interests}

The author(s) declared no potential conflicts of interest with respect to the research, authorship, and/or publication of this article.

\section{Publisher's Note}

Springer Nature remains neutral with regard to jurisdictional claims in published maps and institutional affiliations.

\section{Author details}

'Department of Chemistry, Aligarh Muslim University, Aligarh, Uttar Pradesh 202002, India. ${ }^{2}$ Department of Saidla, Aligarh Muslim University, Aligarh, Uttar Pradesh 202002, India. ${ }^{3}$ Department of Biology, College of Natural and Computational Sciences, University of Gondar, P.O. Box \#196, Gondar, Ethiopia. ${ }^{4}$ Department of IImul Advia (Unani Pharmacy), Aligarh Muslim University, Aligarh, Uttar Pradesh 202002, India.

Received: 17 May 2018 Accepted: 3 September 2018

Published online: 21 September 2018

\section{References}

1. Siddiqi KS, Husen A, Sohrab SS, Osman M. Recent status of nanomaterials fabrication and their potential applications in neurological disease management. Nano Res Lett. 2018:13:231.

2. Husen A, Siddiqi KS. Phytosynthesis of nanoparticles: concept, controversy and application. Nano Res Lett. 2014;9:229.

3. Husen A, Siddiqi KS. Plants and microbes assisted selenium nanoparticles: characterization and application. J Nanobiotechnol. 2014;12:28.

4. Husen A, Siddiqi KS. Carbon and fullerene nanomaterials in plant system. J Nanobiotechnol. 2014;12:16.

5. Siddiqi KS, Husen A. Fabrication of metal nanoparticles from fungi and metal salts: scope and application. Nano Res Lett. 2016;11:98.

6. Siddiqi KS, Husen A. Fabrication of metal and metal oxide nanoparticles by algae and their toxic effects. Nano Res Lett. 2016;11:363.

7. Siddiqi, Husen A. Engineered gold nanoparticles and plant adaptation potential. Nano Res Lett. 2016;11:400.

8. Siddiqi KS, Husen A. Green synthesis, characterization and uses of palladium/platinum nanoparticles. Nano Res Lett. 2016;11:482.

9. Siddiqi KS, Rahman A, Tajuddin HA. Biogenic fabrication of iron/iron oxide nanoparticles and their application. Nano Res Lett. 2016;11:498.

10. Siddiqi KS, Husen A. Recent advances in plant-mediated engineered gold nanoparticles and their application in biological system. J Trace Elements Med Biol. 2017:40:10-23.

11. Siddiqi KS, Husen A, Rao RAK. A review on biosynthesis of silver nanoparticles and their biocidal properties. J Nanobiotechnol. 2018;16:14.

12. Siddiqi KS, Rahman A, Tajuddin HA. Properties of zinc oxide nanoparticles and their activity against microbes. Nano Res Lett. 2018;13:141.

13. Tagad CK, Dugasani SR, Aiyer R, Park S, Kulkarni A, Sabharwal S. Green synthesis of silver nanoparticles and their application for the development of optical fiber based hydrogen peroxide sensor. Sensors Actuators B Chem. 2013:183:144-9.

14. Venkateswarlu S, Kumar BN, Prathima B, Anitha K, Jyothi NW. A novel green synthesis of $\mathrm{Fe}_{3} \mathrm{O}_{4}$-ag core shell recyclable nanoparticles using Vitis vinifera stem extract and its enhanced antibacterial performance. Physica B. 2015; 457:30-5.

15. Rao Y, Kotakadi VS, Prasad TNVKV, Reddy AV, Sai Gopal DVR. Green synthesis and spectral characterization of silver nanoparticles from Lakshmi tulasi (Ocimum sanctum) leaf extract. Spectrochim Acta A. 2013;103:156-9.

16. Husen A. Gold nanoparticles from plant system: synthesis, characterization and their application. In: Ghorbanpourn M, Manika K, Varma A, editors. Nanoscience and plant-soil systems, vol. 48. Switzerland: Springer international publishing AG, Gewerbestrasse 11, 6330 Cham; 2017. p. 455-79.

17. Dhand V, Soumya L, Bharadwaj S, Chakra S, Bhatt D, Sreedhar B. Green synthesis of silver nanoparticles using Coffea arabica seed extract and its antibacterial activity. Mat Sci Eng C. 2016;58:36-43.

18. Latha M, Priyanka M, Rajasekar P, Manikandan R, Prabhu NM. Biocompatibility and antibacterial activity of the Adathoda vasica Linn extract mediated silver nanoparticles. Microb Pathog. 2016;93:88-94. 
19. Tran TA, Kinch L, PeňaLlopis S, Kockel L, Grishin N, Jiang H, Brugarolas J. Platelet-derived growth factor/vascular endothelial growth factor receptor inactivation by sunitinib results in Tsc1/Tsc2-dependent inhibition of TORC1. Mol Cell Biol. 2013:33:3762-79.

20. Austin B, Austin DA. Bacterial fish pathogens. Diseases of farmed and wild fish, springer-praxis publishing, Itd., United Kingdom, 1999.

21. Cai JP, Li J, Thompson KD, Li CX, Han HC. Isolation and characterization of pathogenic Vibrio parahaemolyticus from diseased post-larvae of abalone Haliotis diversicolor supertexta. J Basic Microbiol. 2007;47:84-6.

22. Jayasree $L$, Janakiram P, Madhavi R. Characterization of Vibrio spp. associated with diseased shrimp from culture ponds of Andhra Pradesh (India). J World Aquacult Soc. 2006:37:523-32.

23. Yu X, Guo Q, Su G, Yang A, Hu Z, Qu C, Wan Z, Li R, Tu P, Chai X. Usnic acid derivatives with cytotoxic and antifungal activities from the lichen Usnea longissima. J Nat Prod. 2016;79:1373-80.

24. Favreau JT, Ryu ML, Braunstein G, Orshansky G, Park SS, Goody GL, Love L, Fong TL. Severe hepatotoxicity associated with the dietary supplement LipoKinetix. Ann Intern Med. 2002;136:590-5.

25. Neff GW, Reddy KR, Durazo FA, Meyer D, Marrero R, Kaplowitz N. Severe hepatotoxicity associated with the use of weight loss diet supplements containing ma huang or usnic acid. J Hepatol. 2004;41:1062-4.

26. Guo L, Shi Q, Fang JL, Mei N, Ali AA, Lewis SM, Leakey JEA, Frankos VH. Review of usnic acid and Usnea barbata toxicity. J Environ Sci Health C Environ Carcinog Ecotoxicol Rev. 2008;26:317-38.

27. Wei JC, Wang XY, Wu JL, Wu JN, Chen XL, Hou JL. Lichenes Officinales Sinenses. Beijing: Science press; 1982. p. 18-58.

28. Nishitoba Y, Nishimura I, Nishiyama T, Mizutani J. Lichen acids, plant growth inhibitors from Usnea longissima. Phytochemistry. 1987;26:3181-5.

29. Halici M, Odabasoglu F, Suleyman H, Cakir A, Aslan A, Bayir Y. Effects of water extract of Usnea longissima on antioxidant enzyme activity and mucosal damage caused by indomethacin in rats. Phytomedicine. 2005; 12:656-62.

30. Fernández-Moriano C, Gómez-Serranillos MP, Crespo A. Antioxidant potential of lichen species and their secondary metabolites. A systematic review. Pharm Biol. 2016;54:1-17.

31. Luzina OA, Salakhutdinov NF. Biological activity of usnic acid and its derivatives: part 1. Activity against unicellular organisms. Rus J Bioorg Chem. 2016:42:115-32.

32. Luzina OA, Salakhutdinov NF. Biological activity of usnic acid and its derivatives: part 2. Effects on higher organisms. Molecular and physicochemical aspects. Rus J Bioorg Chem. 2016;42:249-68.

33. Yamamoto $Y$, Miura $Y$, Kinoshita $Y$, Higuchi M, Yamada Y, Murakami A, Ohigashi H, Koshimizu K. Screening of tissue cultures and thalli of lichens and some of their active constituents for inhibition of tumor promoter-induced Epstein-Barr virus activation. Chem Pharm Bull (Tokyo). 1995;43:1388-90.

34. Odabasoglu F, Aslan A, Cakir A, Suleyman H, Karagoz Y, Halici M, Bayir Y. Comparison of antioxidant activity and phenolic content of three lichen species. Phytother Res. 2004;18:938-41.

35. Turhan K, Ekinci-Dogan C, Akcin G, Aslan A. Biosorption of au(III) and cu(II) from aqueous solution by a non-living Usnea longissima biomass. Fres Environ Bull. 2005;14:1129-35.

36. Eugino M, Muller N, Frases S, Almeida-Paes R, Mauricio LMTR, Lemgruber L, Farina M, de-Souza W, Anna CS. Test-derived biosynthesis of silver/silver chloride nanoparticles and their antiproliferative activity against bacteria. RSC Adv. 2016;6:9893-904.

37. Rajput S, Werezuk R, Lange RM, McDermott MT. Fungal isolate optimized for biogenesis of silver nanoparticles with enhanced colloidal stability. Langmuir. 2016;32:8688-97.

38. Zhang JZ, Nogues C. Plasmonic optical properties and applications of metal nanostructures. Plasmonics. 2008;3:127-50.

39. Rajakumar G, Gomathi T, Thiruvengadam M, Rajeswari VD, Kalpana VN, Chung IM. Evaluation of anti-cholinesterase, antibacterial and cytotoxic activities of green synthesized silver nanoparticles using from Millettia pinnata flower extract. Microb Pathogen. 2017;103:123-8.

40. Kalimuthu K, Suresh Babu R, Venkataraman D, Bilal M, Gurunathan S. Biosynthesis of silver nanocrystals by Bacillus licheniformis. Colloids Surf B Biointerf. 2017;65:150-3.

41. Vijay Kumar PPN, Pammi SVN, Kollu P, Satyanarayana KW, Shameem U. Green synthesis and characterization of silver nanoparticles using Boerhaavia diffusa plant extract and their anti bacterial activity. Ind Crop Prod. 2004;52:562-6.
42. Nakamoto K. Infrared and Raman spectra of inorganic and coordination compounds, part a and part B, 2 Vol set, $6^{\text {th }}$ Edition. John Wiley \& Sons, Inc. USA, 2009.

43. Prabhu S, Poulose EK. Silver nanoparticles: mechanism of antimicrobial action, synthesis, medical applications, and toxicity effects. Int Nano Lett. 2012;2:32.

44. Hong $X$, Wen J, Xiong $X$, Hu Y. Shape effect on the antibacterial activity of silver nanoparticles synthesized via a microwave-assisted method. Environ Sci Pollut Res. 2016;23:4489-97.

45. Agnihotri S, Mukherji S, Mukherji S. Size-controlled silver nanoparticles synthesized over the range 5-100 nm using the same protocol and their antibacterial efficacy. RSC Adv. 2014;4:3974-83.

46. Saravanan M, Amelash T, Negash L, Gebreyesus A, Selvaraj A, Rayar V. Deekonda K extracellular biosynthesis and biomedical application of silver nanoparticles synthesized from Baker's yeast. Int J Res Pharm Biomed Sci. 2013;4:822-8

47. Bonnigala B, Aswani Kumar YW, Vinay Viswanath K, Joy Richardson P, Mangamuri UK, Poda S. Anticancer activity of plant mediated silver nanoparticles on selected cancer cell lines. J Chem Pharma Res. 2016;8:276-81.

\section{Ready to submit your research? Choose BMC and benefit from:}

- fast, convenient online submission

- thorough peer review by experienced researchers in your field

- rapid publication on acceptance

- support for research data, including large and complex data types

- gold Open Access which fosters wider collaboration and increased citations

- maximum visibility for your research: over $100 \mathrm{M}$ website views per year

At BMC, research is always in progress.

Learn more biomedcentral.com/submissions 